\title{
Spectral Response of Water Under Different Concentrations of Suspended Sediment: Measurement and Simplified Modeling
}

\author{
J. W. B. Lopes ${ }^{1}$, F. B. Lopes ${ }^{2}$, E. M. de Andrade ${ }^{2}$, L. C. G. Chaves ${ }^{3}$ \& M. G. R. Carneiro ${ }^{2}$ \\ ${ }^{1}$ Federal University of Piauí, Bom Jesus, Brazil \\ ${ }^{2}$ Department of Agricultural Engineering, Federal University of Ceará, Fortaleza, Brazil \\ ${ }^{3}$ Faculty of Technology of the Northeast, Caucaia, Brazil \\ Correspondence: J. W. B. Lopes, Federal University of Piaú State, Campus Prof. Cinobelina Elvas, CEP: \\ 64900-000, Bom Jesus, Brazil. Tel: 55-893-562-2535. E-mail: wellingtonjwl@gmail.com
}

Received: November 22, 2018

Accepted: December 22, 2018

Online Published: February 15, 2019

doi:10.5539/jas.v11n3p327

URL: https://doi.org/10.5539/jas.v11n3p327

\begin{abstract}
Understanding the spectral behaviour of water is of the greatest importance to the quality management of water resources. Continuous monitoring by remote sensing is therefore essential for administrators seeking the efficient management of its many uses. The aim of this research was to characterise the spectral response of water submitted to different concentrations of sediments of varying textural properties, organic matter and salts, and to identify the implications of these characteristics using simplified modelling. The experiment was conducted at the Radiometry Laboratory of the Department of Agricultural Engineering of the Federal University of Ceará, Brazil. The soils used in the research came from two areas of irrigated agriculture in Ceará, one in Morada Nova and the other in Pentecoste. Both soils were classified as Fluvic Neosols; the first saline and the second saline-sodic, and presented significant differences in granulometric composition and organic matter content. From the results, it can be concluded that: (i) sediments added at different concentrations cause an increase and deformation of the reflectance curves, and that maximum spectral partitioning occurs at two reflectance peaks; (ii) derivative analysis favours the identification of wavelengths that best differentiate sediment concentration, allowing more-efficient modelling of the process; (iii) the characteristics of texture, organic matter and salt content have little effect on estimating suspended-sediment concentration in the water, making multiple linear regression modelling a viable option for this purpose.
\end{abstract}

Keywords: remote sensing, water quality, monitoring, spectroradiometry

\section{Introduction}

Monitoring the quality of surface water is a basic tool in managing this resource (Abdelmalik, 2018; Kim et al., 2017), especially in regions where the supply of water for a wide range of uses is almost entirely dependent on surface reservoirs. Population growth and the increased demand for consumer goods have resulted in a significant increase in the number of artificial reservoirs in various areas of the world, such as Australia (Callow \& Smettem, 2009), Brazil (Malveira, de Araújo, \& Güntner, 2012), China (Li \& Wei, 2008), Romania (Rãdoane \& Rãdoane, 2005), Spain (Mamede, 2008), the United States (Minear \& Kondolf, 2009) and Canada (Teegavarapu \& Simonovic, 2002). Despite efficient storage capacity, surface reservoirs are subject to impacts on the quality and quantity of waterdue to the supply of sediment from natural or anthropogenic processes.

The semiarid regions of Brazil are an example of regions where the supply of water is almost entirely dependent on surface reservoirs (Andrade, Araújo, Rosa, Disney, \& Alves, 2007; de Araújo, Güntner, \& Bronstert, 2006; Krol, de Vries, van Oel, \& de Araújo, 2011). In these environments, the risk of water shortage is imminent due to the growth in demand as well as the water supply being restricted to the rainfall history of the previous years and the accumulated volume in the reservoirs (de Araújo \& Bronstert, 2016). Therefore, the availability of water relies on the retention of river flows in the reservoirs, which on its turn is subject to the siltation process and can have serious impacts on the local and regional economy in relation to potable water supply, irrigation and energy supply (Agostinho, Gomes, Santos, Ortega, \& Pelicice, 2016). The reduction in water availability is one of the key impact factors on silting in reservoirs on the semiarid regions. It is estimated that the reduction, for the State of Ceará alone, is approximately $388 \mathrm{~L} \cdot \mathrm{s}^{-1}$ yearly (90\% annual reliability: Campos, 2010; de Araújo et al., 2006). 
Still, qualitatively the reservoirs can be affected by silting since they act as filters able to retain a considerable portion of the sediment carried by rivers (Lima Neto, Wiegand, \& de Araújo, 2011; Lira, Toledo, \& Mamede, 2014). This retained portion, when at high deposition rates, can cause significant increases in nutrient and other water pollutants. The deposition of enriched sediments can have negative environmental consequences, which are detected by changes in indicators of water quality, mainly related to the solubility of salts, nutrients and sediment transport (Andrade et al., 2007).

It is therefore essential to monitor water resources in order to promote measures for controlling and preventing large amounts of sediment in surface reservoirs.

Among the current techniques for monitoring water bodies, remote sensing is important., and has shown great potential for overcoming the spatio-temporal limitations of traditional methods of water monitoring in situ, since it allows the acquisition of information on different spatial and temporal scales (Gin, Koh, \& Lin, 2003; Rudorff, Novo, Galvao, \& Pereira Filho, 2007; Valerio et al., 2018; Wang \& Lu, 2010; Zhang et al., 2016).

With the application of remote-sensing techniques, it is possible to evaluate the responses resulting from disturbances due to anthropogenic activity, so as to predict the impact of such action on the conditions that guarantee maintenance of the environmental quality in the medium and long term (Novo, 2005). Therefore, the relationship between responses in the spectral domain and optically active limnological characteristics are the focus of applying remote sensing to bodies of water. It is sought to understand the dynamics of the composition and biophysical components of water that are relevant to monitoring aquatic ecosystems (Renó et al., 2009).

The difficulty in understanding the dynamics of the composition and optically-active components of water lies in their interactivity, since sediment, due to such characteristics as its granulometric composition, results in changes to spectral response (Lodhi, Rundquist, Han, \& Kuzila, 2007; Ostrovsky \& Tęgowski, 2010). In addition, this sediment is associated and interacts with other optically active components, such as organic matter. The organic matter acts in reducing the bidirectional reflectance factor of the water (Mantovani \& Novo, 1996) in the visible spectrum and promotes increased reflectance in the infrared. Organic matter dissolved in the water causes absorption of the incident energy in the region of the spectrum between 400 and $700 \mathrm{~nm}$ (Bricaud, Morel, \& Prieur, 2018), with a consequent reduction in reflectance. Increases in the concentrations of organic matter in the water also promote an increase in reflectance amplitude in the red and infrared regions (Mobley, 1994).

In view of the above, the aim of this study was to characterise the spectral response of water submitted to different concentrations of two soils of different texture and concentrations of organic matter. It was also sought to identify the relationship between spectral signature and concentration using multiple regression analysis.

\section{Method}

\subsection{Collection of Experimental Data}

The experiment was conducted at the Radiometric Laboratory of the Department of Agricultural Engineering of the Federal University of Ceará (DENA/UFC), Brazil. To minimise interference from variations in the angular position of the sun, all readings were taken under a clear sky from 10:00 to 14:00.

The experiment was carried out in a blue polyethylene container, painted internally with matte black paint. The container had a total capacity of 310 litres; the volume of water used in the experiment was 200 litres (Figure 1). An ASD FieldSpec ${ }^{\circledR} 3$ Hi-Res spectroradiometer, manufactured by Analytical Spectral Devices, was used to measure the radiance. The spectral resolution of this equipment is $1 \mathrm{~nm}$, with a spectral range of from 350 to $2,500 \mathrm{~nm}$. 


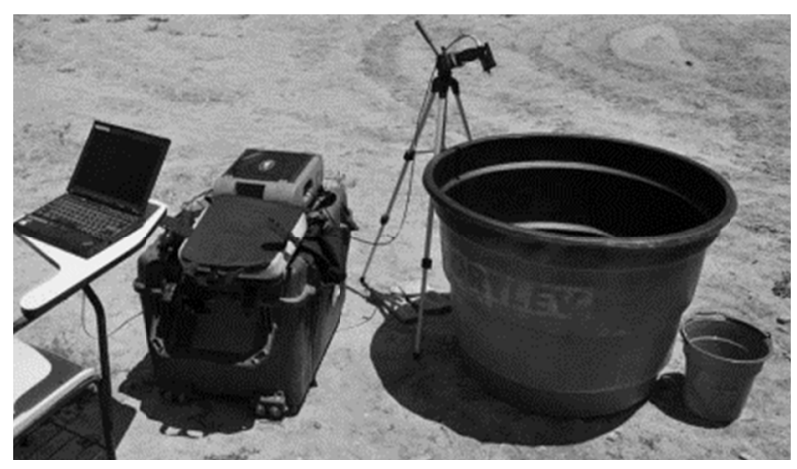

Figure 1. Container and ASD FieldSpec ${ }^{\circledR} 3$ Hi-Res spectroradiometer used in the experiment to collect radiometric data

The wavelength bands to be analysed comprised the 400 to $900 \mathrm{~nm}$ range, corresponding to the range of the optically active components of the water. A Spectralon reference plate, to represent a Lambertian surface, was used in measuring the radiance, since it has a similar reflectance to that of a perfect Lambertian surface.

Radiance values were converted to reflectance factor with Equation 1.

$$
F R B_{\lambda}=\left(L_{a, \lambda} / L_{r, \lambda}\right) \times 100
$$

where, $F R B_{\lambda}=$ bidirectional reflectance factor (\%); $L_{a, \lambda}=$ spectral radiance of the target $\left(\mathrm{W} \mathrm{cm}^{-2} \mathrm{sr} \mu \mathrm{m}\right) ; L_{r, \lambda}=$ spectral radiance reference $\left(\mathrm{W} \mathrm{cm}^{-2} \mathrm{sr} \mu \mathrm{m}\right)$.

Spectral readings began using clear water (with no added sediment). After each reading (i.e. five sequences of data acquisition) a known amount of sediment was added (Table 1), and a reading was taken.

Table 1. Weight of sediment added to the water according to concentration

\begin{tabular}{llll}
\hline \multirow{n}{*}{$\mathrm{n}$} & \multirow{2}{*}{$\operatorname{SSC}\left(\mathrm{mg} \mathrm{L}^{-1}\right)$} & \multicolumn{2}{c}{ Weight of sediment $(\mathrm{g})$} \\
\cline { 3 - 4 } & & Added & Accumulated \\
\hline 1 & 0 & 0 & 0 \\
2 & 50 & 10 & 10 \\
3 & 100 & 10 & 20 \\
4 & 150 & 10 & 30 \\
5 & 300 & 30 & 60 \\
6 & 400 & 20 & 80 \\
7 & 700 & 60 & 140 \\
8 & 900 & 40 & 180 \\
9 & 1250 & 70 & 250 \\
10 & 1500 & 50 & 300 \\
\hline
\end{tabular}

Note: $\mathrm{n}=$ concentration number; $\mathrm{SSC}=$ suspended-sediment concentration $\left(\mathrm{mg} \mathrm{L}^{-1}\right)$.

The soils used in this research came from two regions of irrigated agriculture in the State of Ceará, one in Morada Nova $\left(\operatorname{RUbd}_{l}\right)$ and the other in Pentecoste $\left(\operatorname{RUbd}_{2}\right)$, both classified as Fluvic Neosols $\left(\mathrm{RUbd}_{i}\right)$. The average geographic coordinates of the central points of the areas $\mathrm{RUbd}_{l}$ and $\mathrm{RUbd}_{2}$ are $5^{\circ} 10^{\prime} \mathrm{S}, 38^{\circ} 22^{\prime} \mathrm{W}$ and $3^{\circ} 45^{\prime} \mathrm{S}, 39^{\circ} 14^{\prime} \mathrm{W}$, respectively.

According to the physical-chemical analysis carried out, $\mathrm{RUbd}_{l}$ is classified as a saline soil and $\mathrm{RUbd}_{2}$ as a saline-sodic soil. In addition to the above difference, it should be noted that although the soils have the same classification, they display significant differences in granulometric composition and the amount of organic matter (Table 2). 
Table 2. Soil characteristics

\begin{tabular}{|c|c|c|c|c|c|c|c|}
\hline \multirow{2}{*}{ Soil } & \multicolumn{3}{|c|}{ Granulometric composition (\%) } & \multirow{2}{*}{$\mathrm{EC}\left(\mathrm{dS} \mathrm{m} \mathrm{m}^{-1}\right)$} & \multirow{2}{*}{ ESP } & \multirow{2}{*}{$\mathrm{OM}\left(\mathrm{g} \mathrm{kg}^{-1}\right)$} & \multirow{2}{*}{ Textural class } \\
\hline & Sand & Silt & Clay & & & & \\
\hline $\mathrm{RUbd}_{i}$ & 13 & 81 & 6 & 31.63 & 2 & 32.3 & silty \\
\hline $\mathrm{RUbd}_{2}$ & 18 & 51 & 31 & 13.72 & 73 & 14.0 & clayey loam \\
\hline
\end{tabular}

Note. $\mathrm{RUbd}_{l}=$ saline Fluvic Neosol from the Morada Nova irrigated perimeter, Ceará; $\mathrm{RUbd}_{2}=$ saline-sodic Fluvic Neosol from the Pentecoste irrigated perimeter, Ceará; EC = electric conductivity; ESP = exchangeable sodium percentage; $\mathrm{OM}=$ organic matter.

\subsection{Data Analysis}

Derivative analysis is a technique that makes use of the derivative value of reflectance with respect to wavelength. This allows identification of the points at which the spectral curve displays abrupt changes in behaviour due to the presence of components that favour absorption and scattering of the target. Derivative analysis was therefore used to evaluate more accurately the wavelength at which spectral changes occurred in relation to the sediment concentrations under investigation.

The first derivative $(\mathrm{dR} \lambda)$ of the reflectance spectrum with respect to wavelength $\mathrm{x}$ at a given point $\mathrm{i}$ can be numerically approximated by a finite-difference scheme using central or symmetric approximation, expressed by Equation 2.

$$
\frac{d R_{\lambda}}{d x} \cong \frac{R_{i+1}-R_{i-1}}{2 \Delta x}
$$

where, $\Delta x$ is the separation between two successive bands. Since $\Delta x=x_{j}-x_{k}$, it is assumed that $x_{j}>x_{k}$ and the interval between the bands is constant. From the results obtained with the derivative analysis, a multiple regression analysis was carried out in order to establish empirical models for estimating the suspended-sediment concentration in the water from the reflectance data.

In order to evaluate the performance of the resulting models, the following criteria based on statistical indices were used: coefficient of determination $\left(r^{2}\right)$, which indicates the degree of correlation between the independent variables and the dependent variable; Pearson correlation coefficient ( $r$ ) (Equation 3); and the concordance index (d) proposed by Willmott (1981), that indicates the degree of precision of the equation (Equation 4) and can assume values from 0 (zero) to 1 , for the no agreement and perfect agreement, respectively. The confidence index of the model (c) was also analysed, which includes the indications of the two coefficients, $r$ and $d,(\mathrm{c}=\mathrm{r} \cdot \mathrm{d})$ where $\mathrm{c}=1$ means perfect confidence and $\mathrm{c}=0$ zero confidence, as proposed by Camargo and Sentelhas (1997). Finally, the measured and simulated data were evaluated using the efficiency coefficient proposed by Nash and Sutcliffe (1970) (Equation 5). The NSE coefficient varies from - $\infty$ to 1, and the greater the coefficient, the better the performance of the model. If the NSE is less than 0 (zero), the predictive capacity of the model is less than the measured mean value.

Different reflectance data were used in this analysis to those used in calibrating the models, thereby avoiding errors resulting from autocorrelation of the data, which could result in the models giving skewed results. The reflectance data for the selected wavelengths that were used in the calibration step constitute a mean of a set of three values obtained for each concentration of suspended sediment $\left(0\right.$ to $\left.1500 \mathrm{mg} \mathrm{L}^{-1}\right)$. The reflectance data for the same wavelengths used to model the SSC from the regression models evaluated correspond to the mean obtained from the two remaining values of the readings repetitions (as previously described, at each stage of addition of sediments were performed a sequence of five repetitions of readings).

Thus, it was possible to perform the SSC simulations from the empirical models with reflectance data not used in the elaboration of the equations, allowing the comparison with the measured suspended sediment concentration.

$$
\begin{gathered}
\mathrm{r}=\frac{\sum_{\mathrm{i}=1}^{\mathrm{n}}\left(\mathrm{M}_{\mathrm{i}}-\overline{\mathrm{M}}\right)\left(\mathrm{E}_{\mathrm{i}}-\overline{\mathrm{E}}\right)}{\sqrt{\sum_{\mathrm{i}=1}^{\mathrm{n}}\left(\mathrm{M}_{\mathrm{i}}-\overline{\mathrm{M}}\right)^{2}} \sqrt{\sum_{\mathrm{i}=1}^{\mathrm{n}}\left(\mathrm{E}_{\mathrm{i}}-\overline{\mathrm{E}}\right)^{2}}} \\
\mathrm{~d}=1-\frac{\sum_{\mathrm{i}=1}^{\mathrm{n}}\left(\mathrm{E}_{\mathrm{i}}-\mathrm{M}_{\mathrm{i}}\right)^{2}}{\sum_{\mathrm{i}=1}^{\mathrm{n}}\left(\left|\mathrm{E}_{\mathrm{i}}-\overline{\mathrm{M}}\right|-\left|\mathrm{M}_{\mathrm{i}}-\overline{\mathrm{M}}\right|^{2}\right)} \\
\mathrm{NSE}=1-\frac{\sum_{\mathrm{i}=1}^{\mathrm{n}}\left(\mathrm{M}_{\mathrm{i}}-\mathrm{E}_{\mathrm{i}}\right)^{2}}{\sum_{\mathrm{i}=1}^{\mathrm{n}}\left(\mathrm{M}_{\mathrm{i}}-\overline{\mathrm{M}}\right)^{2}}
\end{gathered}
$$


where, $E$ : estimated suspended-sediment concentration (SSC) value, $\mathrm{mg} \mathrm{L}^{-1} ; \bar{E}$ : mean value of the estimated $\mathrm{SSC}$ values, $\mathrm{mg} \mathrm{L}^{-1} ; M$ : measured SSC value, $\mathrm{mg} \mathrm{L}^{-1} ; \bar{M}$ : mean value of the measured SCC values, $\mathrm{mg} \mathrm{L}^{-1} ; n$ : number of measurements.

\section{Results and Discussion}

\subsection{Relationship Between Reflectance and Sediment Concentration in the Water}

In the absence of suspended sediments, the reflectance of the water in the container ranges from $0.5 \%$ to around $1.5 \%$ (Figure 2). The low reflectance values was mainly due to the absence of optically active material in the water, causing the black inner walls of the container to absorb almost all the incident energy. For clear water, maximum reflectance is recorded at around $400 \mathrm{~nm}$, with discrete secondary peaks at $700 \mathrm{~nm}$ and $800 \mathrm{~nm}$ - this effect can be seen in the research by Rudorff et al. (2007). The greatest absorption is seen in the near-infrared band - beyond $750 \mathrm{~nm}$, since, as there is no notable presence of organic matter or suspended solids, the water absorbs a significant part of the incident radiation in the near infrared band (Jensen, 2007).

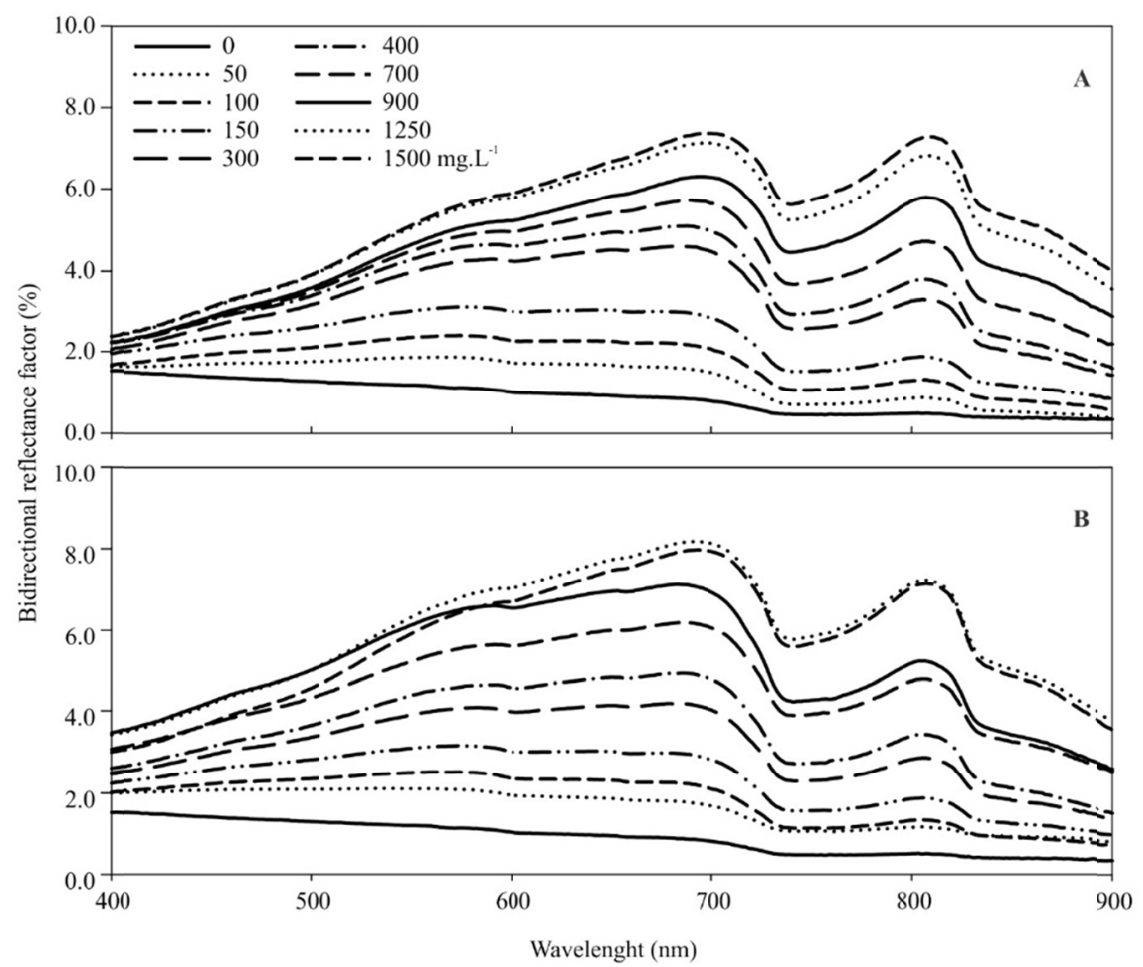

Figure 2. Spectral curves of the water as a function of sediment concentration for saline (A) and saline-sodic (B)

Fluvic Neosols. The values for sediment concentration was expressed in $\mathrm{mg} \mathrm{L}^{-1}$, ranging from 0 to 1500

Successive increases in the suspended-sediment load result in a shift in the spectral reflectance profile towards higher values. This can also be found in other studies, such as those by Chen, Curran, and Hansom (1992); Curran and Novo (1988); Karabulut and Ceylan (2005) and Lodhi et al. (2007), who state that a higher concentration of suspended sediment causes an increase in reflectance over the entire spectral band from $400 \mathrm{~nm}$ to $900 \mathrm{~nm}$.

According to the spectral responses of the water system for the two soils evaluated in this experiment, they were similar, i.e. the curves have radiation-absorption bands around $400 \mathrm{~nm}, 750 \mathrm{~nm}$ and $900 \mathrm{~nm}$, and due to the absorption and scattering produced by the water molecules and sediment particles in these bands, there was two prominent reflectance peaks, at $700 \mathrm{~nm}$ and $800 \mathrm{~nm}$ (Figure 2). It can also be seen that with the addition of sediment, there is a rise in reflectance in the 400 to $675 \mathrm{~nm}$ range, with a crest at $700 \mathrm{~nm}$ followed by an abrupt decrease trough from $725 \mathrm{~nm}$. Reflectance then starts to increase up to $800 \mathrm{~nm}$, followed by a reduction, characterising a second reflectance peak. Rudorff et al. (2007) saw a similar effect on the radiation-absorption bands for the waters of the Amazon River, and attributed these absorption bands to the joint spectral properties of 
the suspended sediments and dissolved organic matter (close to the $450 \mathrm{~nm}$ band), and by rotation of the water molecules (750 $\mathrm{nm}$ and $900 \mathrm{~nm})$.

It can also be seen that for the same sediment concentration, spectral reflectance values was slightly higher for the soil with a greater sediment content of smaller particle size, i.e. clay (Figure 2B). In fact, for suspended particles with diameters smaller than $63 \mu \mathrm{m}$, the maximum reflection coefficient is $11 \%$ at $570 \mathrm{~nm}$ (Gin et al., 2003), while for sediment smaller than $10 \mu \mathrm{m}$, the maximum reflectance at the same wavelength is $15 \%$.

For the saline soil (Figure 2A), reflectance values was similar between the peaks (700 nm and $800 \mathrm{~nm}$ ), in contrast to the saline-sodic soil (Figure 2B), where the values of the first peak was higher than those of the second. These findings support the hypothesis that organic matter present in larger proportion in saline soil has the effect of reducing reflectance in the $400 \mathrm{~nm}$ to $700 \mathrm{~nm}$ range, and at the same time promotes a substantial increase in reflectance around $800 \mathrm{~nm}$.

It is known that the presence of organic matter reduces the reflectance of both silt and clay particles, which, despite being fractions of smaller diameter, undergo changes due to organic matter. Clay particles in the presence of more organic matter have a darker colour and result in lower reflectance values at all wavelengths compared to silty soil (Lodhi et al., 2007).

The greatest reflectance value, which occurred around $800 \mathrm{~nm}$ for the saline soil (soil with a higher concentration of organic matter) confirms the findings of (Mantovani \& Novo, 1996). Those authors report that the greatest increase in the bidirectional reflectance factor as a function of organic matter concentration occurs at around $800 \mathrm{~nm}$.

Increases in the concentration of dissolved organic matter found in water systems decreases reflectance, especially in the blue to red range. In the spectral range between 400 and $570 \mathrm{~nm}$ (blue and green), concentrations of humic substances promote a reduction of approximately $40 \%$ in water reflectance. In the red and infrared region, 670 and $900 \mathrm{~nm}$, there is a proportional increase in reflectance amplitude throughout the range (Mobley, 1994).

However, it is important to highlight the uncertainties that may occur due to factors in the field, such as the variation in days and times of measurements; variations in irradiance and in solar illumination geometry during data collection; specular reflectance; and movement of the water surface caused by the wind, which intensifies the effects of the specular reflectance (Rudorff et al., 2007).

The most relevant characteristic of the spectral curves is the predominance of two reflectance peaks. These two crests tend to become narrower and more prominent as more sediment is added. Maximum spectral partitioning (rate of increase of peak reflectance at each concentration) for both soils can be seen at the wavelength bands corresponding to the reflectance peaks. The formation of two reflectance peaks in the spectral profile when sediment is added to the water is a fact resulting from this study, and is also seen in other studies, such as those of (Lodhi et al., 2007; Rudorff et al., 2007).

With the reflectance curves for $1,250 \mathrm{mg} \mathrm{L}^{-1}$ and $1,500 \mathrm{mg} \mathrm{L}^{-1}$ of sediment, an increase in suspended-sediment concentration does not result in an increase in reflectance, i.e. there is low spectral separation, in such a way that an increase in sediment concentration results in no significant increase in reflectance. Cloud cover and energy intensity in the environment (Gin et al., 2003) are factors that cause these variations, however experimental conditions during this research minimised the action of these factors. Another important factor, and one that may have exerted greater influence, is the granulometric and mineralogical composition of the soil (Curran \& Novo, 1988), especially sediment properties. The influence of granulometric composition should explain the result described here, associating water saturation by the suspended-sediment load with the deposition rate, which tends to be greater at high concentrations.

\subsection{Relationship Between the First-Order Derivative and Sediment Concentration in the Water}

After differentiating the reflectance curves for both soils (Figure 3), it was found that the first spectral derivative applied to reflectance reduced variations from the constant addition of radiation at both levels of data acquisition, highlighting certain spectral features. With these curves, the variation pattern was similar for each simulated concentration of suspended-sediment in the water. First there was a negative peak around $725 \mathrm{~nm}$, followed by a positive rise to $800 \mathrm{~nm}$, with the subsequent formation of another, more-pronounced negative peak around 825 $\mathrm{nm}$. These findings for spectral behaviour are explained by the combined effect that the spectral properties of the suspended sediments and dissolved organic matter together promote in the water. For Rudorff et al. (2007), these joint properties of the dissolved elements translate into standard spectral behaviour of changes in the reflectance and absorption peaks. 


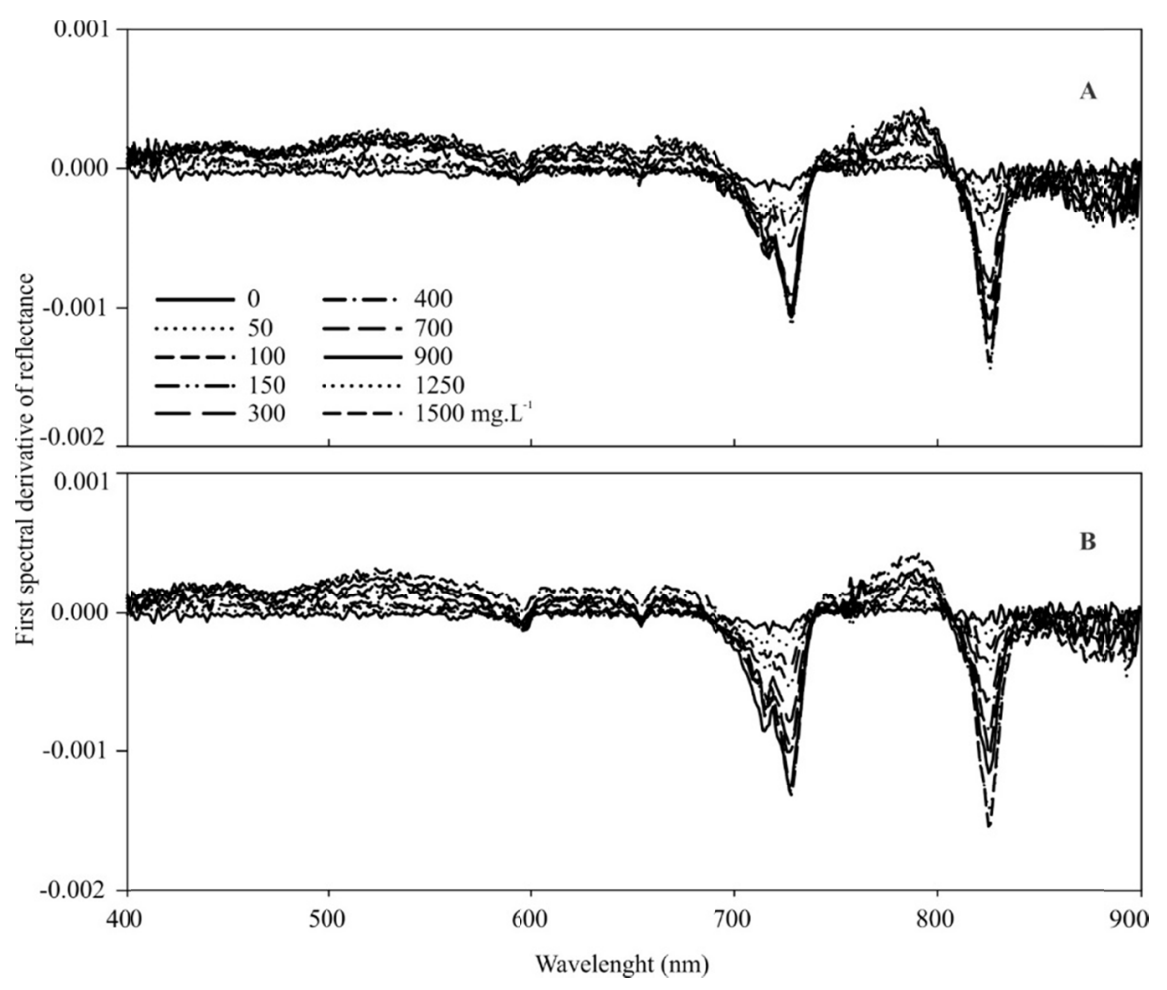

Figure 3. Derivative curves of the water spectrum with different concentrations of suspended sediment for saline (A) and saline-sodic (B) Fluvic Neosols. The values for sediment concentration are expressed in $\mathrm{mg} \mathrm{L}^{-1}$, and range from 0 to 1500

By means of derivative analysis of the data it was possible to identify points where the spectral curve showed abrupt changes in behaviour due to the presence of sediment in the water, and from this to define the spectral bands that allow the suspended-sediment concentration to be estimated by means of multiple linear regression models, and to analyse the relationship between sediment and spectral response. As the higher-contrast spectral bands in the differentiation were the same for both soils under evaluation, the data were grouped, and the mean values used to calibrate the models.

\subsection{Multiple Linear Regression Models for Estimating Sediment Concentration}

In view of the statistical data analysis, important information on the dispersive behaviour of the SSC and reflectance data is required. It can be seen that there are distinct patterns in two regions of the reflectance spectrum in relation to sediment concentration. A linear response is seen when the sediment concentration ranges from 0 to $300 \mathrm{mg} \mathrm{L}^{-1}$. The relationship between reflectance factor and sediment concentration from $300 \mathrm{mg} \mathrm{L}^{-1}$, shows different behaviour, with the mean data better adjusted to a logarithmic curve (Figure 4). In addition, another relevant factor is that mean spectral separability is about twice as high (36\%) for lower concentrations of sediment (i.e. less than $300 \mathrm{mg} \mathrm{L}^{-1}$ ) than for higher values $(16 \%)$. It can therefore be inferred that estimates of sediment concentration may be less susceptible to error when the models are divided into bands (Dorji et al., 2016). 


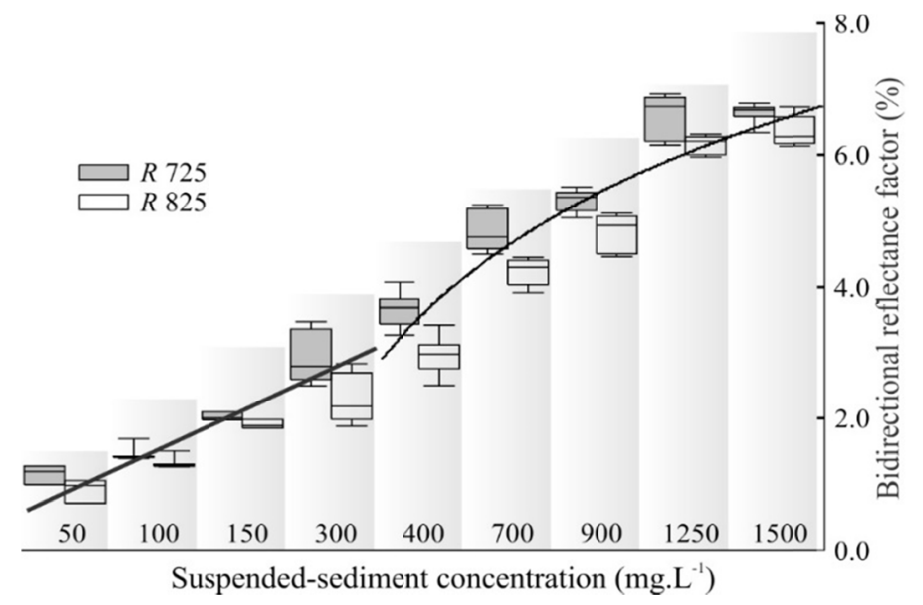

Figure 4. Boxplot of reflectance values and trendlines of mean values for Fluvic Neosols at wavelengths of 725 $\mathrm{nm}(\mathrm{R} 725)$ and $825 \mathrm{~nm}(\mathrm{R} 825)$

These findings support analysis of the data and models according to the above ranges of sediment concentration. As a result, the regression analysis was divided into two parts, the first, which includes the range of 0 to $300 \mathrm{mg}$ $\mathrm{L}^{-1}$, and the second, for values greater than $300 \mathrm{mg} \mathrm{L}^{-1}$.

In addition, in order to verify the degree of interference that salts in the sediment may have in estimating the suspended-sediment load, the saline and saline-sodic soils were parameterised individually.

In addition, even with the above mentioned findings, the data set used separately was combined in the calibration of a general model so as to verify the depreciation of the model when used in a generalized way without previous analysis of the dispersive behavior of the data.

The adjusted multiple linear regression models (Table 3) show good representativeness, with values for $\mathrm{R}^{2}$ and $\mathrm{R}^{2}$ adjusted greater than 0.93 , indicating strong correlation, according to the Pearson scale. The good representativeness of the models was associated to the fact that multiple linear regression makes use of distinct and partially independent wavelength bands, providing a better fit to the data.

Table 3. Multiple linear regression models for estimating suspended-sediment concentration (SSC) from reflectance data

\begin{tabular}{lllll}
\hline Fluvic Neosol & $\mathrm{SSC}$ & Equation & $\mathrm{R}^{2}$ & $\mathrm{R}_{\text {ajusted }}^{2}$ \\
\hline Saline & $0-300$ & $\mathrm{SCC}_{\mathrm{S} 1}=-58.5+(12397.3 \cdot R 725)-(2300.3 \cdot R 825)$ & 0.998 & 0.996 \\
& $>300$ & $\mathrm{SCC}_{\mathrm{S} 2}=-286.9-(22070.6 \cdot R 725)+(48754.5 \cdot R 825)$ & 0.987 & 0.979 \\
\hline Saline-sodic & $0-300$ & $\mathrm{SCC}_{\mathrm{SS} 1}=-90.4+(23181.8 \cdot R 725)-(13280.8 \cdot R 825)$ & 0.983 & 0.966 \\
\hdashline General model & $>300$ & $\mathrm{SCC}_{\mathrm{SS} 2}=-364.0-(1833.5 \cdot R 725)+(29766.7 \cdot R 825)$ & 0.959 & 0.932 \\
\hline
\end{tabular}

Note. General model $=$ model for both soils by fitting all the data together; SSC = suspended-sediment concentration $\left(\mathrm{mg} \mathrm{L}^{-1}\right)$; R725 and R825 = bidirectional reflectance factor (dimensionless-see Equation 1, the radiance measured on the surface of the Spectralon plate as reference) at wavelengths of $725 \mathrm{~nm}$ and $825 \mathrm{~nm}$.

Figure 5 shows the measured values and those modelled by the equations proposed for the soils, providing crossvalidation of the data with saline characteristics against saline-sodic, and vice versa. Also presented are the values simulated by the general model from the reflectance data of the water with saline and saline-sodium sediments. It can be seen that the best fit between the measured and the modelled values for SSC occurs up to $150 \mathrm{mg} \mathrm{L}^{-1}$; from this concentration on, the values differ more. Nevertheless, any related errors are less than $10 \%$, except for the general model, where the mean error up to $150 \mathrm{mg} \mathrm{L}^{-1}$ was greater than $42 \%$ and approximately $32 \%$ at the immediately higher concentrations. 


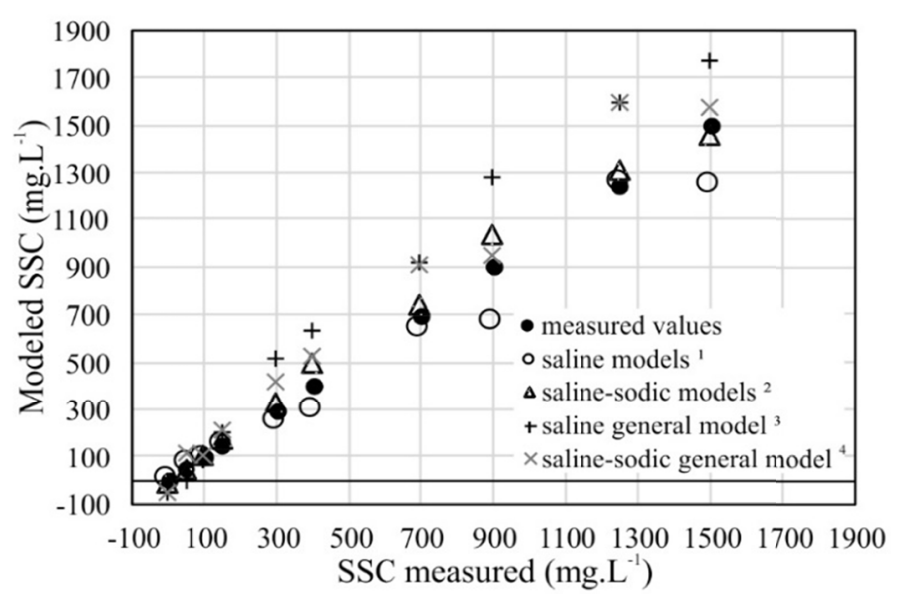

Figura 5. Measured values and values modelled by the equations proposed for the soils

Note. $\mathrm{SSC}=$ suspended-sediment concentration; ${ }^{1}$ mensured reflectance values in saline used for cross-validation of the saline-sodic model; ${ }^{2}$ mensured reflectance values in saline-sodic used for cross-validation of the saline model; ${ }^{3}$ mensured reflectance values in saline used for validation of the general model; ${ }^{4}$ mensured reflectance values in saline-sodic used for validation of the general model.

The specific models for each soil underestimates the values for higher concentrations of sediment in the water (e.g. $1500 \mathrm{mg} \mathrm{L}^{-1}$ ), while the general model overestimates the concentrations. This characterized a limitation of multiple linear regression for modelling data of suspended-sediment concentrations from reflectance data fitted logarithmically. Moreover, there is the limited applicability of the empirical models that, for Lopes, Barbosa, Novo, Andrade, and Chaves (2014), useful only within the context from which they were determined and with the aid of real field data.

The best fit found for the first range of concentrations is related to three factors: the linearity of the data, the efficiency in adjusting the multiple linear model to the linear data and non-saturation of the water by suspended sediments.

As reported above, the concentration of suspended sediments changes the rate of deposition, which tends to be more dynamic at higher concentrations. According to Glymph (1973), the amount of sediment deposited in a given reservoir depends on the amount of suspended material it receives and the capacity of the reservoir to retain the suspended particles (retention efficiency).

By analogy to lentic and lotic bodies of water, the sedimentation ratio itself presents a similar general pattern, where the larger particles, including the bed material load, are seen to sediment, forming a delta, while the lighter particles, especially clay, are distributed beyond the interior of the body of water (Bondurant \& LiveSey, 1973; Yang, Sokoletsky, Wei, \& Shen, 2017). Such material may interact with the dissolved salts, producing flocculation, or even remain in suspension for long periods of time, thereby maintaining high turbidity in the reservoir. There are also very fine sediment particles that are only deposited under conditions of reduced water turbulence; these particles are able to remain in suspension for long periods (Okumura, 1995).

From joint analysis of the concordance index (d), the correlation coefficient (r) and the confidence index (c), it can be seen that the specific multiple linear regression models display good reliability, indicating that the SSC variable can be best estimated with precision and accuracy from the use of specific empirical models, since these present a high degree of reliability, to the detriment of more general models. According to the analysis criteria of Camargo and Sentelhas (1997), the models are classified as having optimal performance.

The calculated NSE coefficients confirm the results of the other indices regarding model performance. The lowest value for NSE is associated with material with saline characteristics at higher concentrations, probably due to the interaction of the dissolved salts with the water. In general terms, such results demonstrate that the models have a wide range of applicability, and that the characteristic properties of the salts do not significantly interfere in the performance of the models (Table 4). It was observed that the general model presented lower efficiency value of the NSE coefficient for the lower SSC values, corroborating with the larger average errors described previously. Even with the lowest efficiency, it was observed that under laboratory conditions the 
general models allow the grouping of a larger number of non-explanatory random variables, makes it feasible and applicable in certain situations.

Table 4. Results of the evaluate the performance of the models for Fluvic Neosol

\begin{tabular}{llllll}
\hline Model & SSC & r & d & c & NSE \\
\hline \multirow{2}{*}{ Saline } & $0-300$ & 0.99 & 0.99 & 0.98 & 0.95 \\
& $>300$ & 0.97 & 0.96 & 0.93 & 0.84 \\
Saline-sodic & $0-300$ & 0.99 & 0.99 & 0.99 & 0.96 \\
\hdashline General model & $>300$ & 0.99 & 0.98 & 0.98 & 0.95 \\
& $0-300$ & 0.98 & 0.93 & 0.91 & 0.54 \\
\hline
\end{tabular}

Note. $\mathrm{SSC}=$ suspended-sediment concentration $\left(\mathrm{mg} \mathrm{L}^{-1}\right) ; \mathrm{r}=$ Pearson correlation coefficient; $\mathrm{d}=$ concordance index; $\mathrm{c}=$ confidence index of the models; NSE $=$ Nash-Sutcliffe efficiency coefficient.

Despite the good results presented in this research, it is necessary to discuss that the laboratory conditions to which the models were developed may not offer the conditions of applicability in the monitoring of the bodies of water. This is due to the fact that the suspended sediments originate in different sources and the proportion that each source contributes in the blend is variable in the time and the space, consequence of the erosive processes that are in course in the contribution basin. Even growth methods that are based on measures and comparisons between measures; which admit the fundamental principle that suspended sediments maintain some of their acquired geochemical properties in the sources, and these properties are then used as tracers for efficiency; have limitations on the applicability in watersheds and differentiation of sediment sources. An example of this is the fingerprinting technique (Collins \& Walling, 2002; Minella, Merten, \& Clarke, 2009; Poleto, Merten, \& Minella, 2009; Tiecher et al., 2018).

Thus the temporal dynamics of sediment in the catchment as well as the different sources (e.g. roads, crops, pastures, fluvial channel), induce the necessity of larger models as opposed to specific models for different types of soil. Although general models have lower efficiency under laboratory conditions, they may overcome the problem of the innumerable sources of variation that sediments may present. For example, the sites where the soil samples were collected are characterized as being of intense agricultural use and in some cases without the adoption of conservation practices, which can cause high rates of soil loss and sediment production that, when they reach the bodies of water cause significant damage. Despite this logic of establishing that agricultural areas contribute more to sediment production, studies by Croke, Mockler, Fogarty, and Takken (2005); Foltz, Copeland, and Elliot ( 2009); Navarro-Hevia, Lima-Farias, de Araújo, Osorio-Peláez, and Pando (2016) e Ziegler et al. (2007) showed that unpaved roads were significant sources of runoff and sediment production, albeit to a lesser extent. In addition, erosion rates produced on roads were much higher (or at least similar) than the usual erosion rates dating back to agricultural fields (Cao, Zhang, \& Zhang, 2009; Rijsdijk, Sampurno Bruijnzeel, \& Sutoto, 2007).

These findings suggest that the monitoring conditions of the bodies of water from specific models for soils of agricultural area may not represent the share of sediments in the water from significant sources, such as unpaved rural roads. These questions highlight the need for monitoring and continuity of research in order to overcome the limited applicability of the empirical models that, for Lopes et al. (2014), are useful only within the context from which they were determined and with the aid of real field data.

\section{Conclusions}

The results obtained in this research, under controlled laboratory conditions, allowed to conclude that:

Different concentrations of suspended sediments in the water causes an increase and deformations in the reflectance curves for the bands corresponding to the optically active components, with maximum spectral partitioning correlated with the predominance of two reflectance peaks that were more intense at higher sediment concentrations.

The technique of derivative analysis was promising in identifying points on the spectral curve for differentiating between sediment concentrations, thereby allowing the elaboration of more-efficient regression models for the wavelength where the spectral changes occurred in relation to the sediment concentrations under study. 
The use of multiple linear regression models was a viable alternative for estimating sediment concentration in surface waters, in such a way that the characteristics of texture, organic matter and salt content do little to interfere in modelling the concentration of suspended-sediments in the water.

It is necessary to use the empirical models in field conditions, in order to verify the applicability of the method in the estimation of the sediment concentration in the bodies of water and in the monitoring of the water quality from the reflectance data. Thus, allowing to evaluate the interference that soil heterogeneity in a catchment, the temporal dynamics of suspended sediments and field conditions different from those in controlled laboratory experiments, can generate in the estimates.

\section{References}

Abdelmalik, K. W. (2018). Role of statistical remote sensing for Inland water quality parameters prediction. The Egyptian Journal of Remote Sensing and Space Science, 21(2), 193-200. https://doi.org/10.1016/J.EJRS. 2016.12.002

Agostinho, A. A., Gomes, L. C., Santos, N. C. L., Ortega, J. C. G., \& Pelicice, F. M. (2016). Fish assemblages in Neotropical reservoirs: Colonization patterns, impacts and management. Fisheries Research, 173, 26-36. https://doi.org/https://doi.org/10.1016/j.fishres.2015.04.006

Andrade, E. M., Araújo, L. F. P., Rosa, M. F., Disney, W., \& Alves, A. B. (2007). Seleção dos indicadores da qualidade das águas superficiais pelo emprego da análise multivariada. Engenharia Agríccola, Jaboticabal, 27(3), 683-690. https://doi.org/10.1590/S0100-69162007000400011

Bondurant, D. C., \& LiveSey, R. H. (1973). Reservoirs Sedimentations Studies. In W. C. Ackermann, G. F. White, E. B. Worthington, \& J. L. Ivens (Eds.), Man-Made Lakes: Their Problems and Environmental Effects (American G). Washington, D. C.: American Geophysical Union. https://doi.org/10.1029/GM017

Bricaud, A., Morel, A., \& Prieur, L. (2018). Absorption by dissolved organic matter of the sea (yellow substance) in the UV and visible domains. Limnology and Oceanography, 26(1), 43-53. https://doi.org/10.4319/lo.19 81.26.1.0043

Callow, J. N., \& Smettem, K. R. J. (2009). The effect of farm dams and constructed banks on hydrologic connectivity and runoff estimation in agricultural landscapes. Environmental Modelling \& Software, 24(8), 959-968. https://doi.org/10.1016/J.ENVSOFT.2009.02.003

Camargo, A. P. de, \& Sentelhas, P. C. (1997). Avaliação do desempenho de diferentes métodos de estimativa da evapotranspiração potencial no estado de São Paulo, Brasil. Revista Brasileira de Agrometeorologia, 8(1), 89-97.

Campos, J. N. B. (2010). Modeling the Yield-Evaporation-Spill in the Reservoir Storage Process: The Regulation Triangle Diagram. Water Resources Management, 24(13), 3487-3511. https://doi.org/10.1007/s11269010-9616-x

Cao, L., Zhang, K., \& Zhang, W. (2009). Detachment of road surface soil by flowing water. CATENA, 76(2), 155-162. https://doi.org/10.1016/j.catena.2008.10.005

Chen, Z., Curran, P. J., \& Hansom, J. D. (1992). Derivative reflectance spectroscopy to estimate suspended sediment concentration. Remote Sensing of Environment, 40(1), 67-77. https://doi.org/10.1016/0034-4257 (92)90127-6

Collins, A., \& Walling, D. (2002). Selecting fingerprint properties for discriminating potential suspended sediment sources in river basins. Journal of Hydrology, 261(1-4), 218-244. https://doi.org/10.1016/S00 22-1694(02)00011-2

Croke, J., Mockler, S., Fogarty, P., \& Takken, I. (2005). Sediment concentration changes in runoff pathways from a forest road network and the resultant spatial pattern of catchment connectivity. Geomorphology, 68(3-4), 257-268. https://doi.org/10.1016/j.geomorph.2004.11.020

Curran, P. J., \& Novo, E. M. M. (1988). The relationship between suspended sediment concentration and remotely sensed spectral radiance: A review. Journal of Coastal Research, 4(3), 351-368.

de Araújo, J. C., \& Bronstert, A. (2016). A method to assess hydrological drought in semi-arid environments and its application to the Jaguaribe River basin, Brazil. Water International, 41(2), 213-230. https:/doi.org/ 10.1080/02508060.2015.1113077 
de Araújo, J. C., Güntner, A., \& Bronstert, A. (2006). Loss of reservoir volume by sediment deposition and its impact on water availability in semiarid Brazil. Hydrological Sciences Journal, 51(1), 157-170. https://doi.org/10.1623/hysj.51.1.157

Dorji, P., Fearns, P., Broomhall, M., Dorji, P., Fearns, P., \& Broomhall, M. (2016). A semi-analytic model for estimating total suspended sediment concentration in turbid coastal waters of northern western Australia using MODIS-Aqua $250 \mathrm{~m}$ data. Remote Sensing, 8(7), 556. https://doi.org/10.3390/rs8070556

Foltz, R. B., Copeland, N. S., \& Elliot, W. J. (2009). Reopening abandoned forest roads in northern Idaho, USA: Quantification of runoff, sediment concentration, infiltration, and interrill erosion parameters. Journal of Environmental Management, 90(8), 2542-2550. https://doi.org/10.1016/j.jenvman.2009.01.014

Gin, K. Y. H., Koh, S. T., \& Lin, I. I. (2003). Spectral irradiance profiles of suspended marine clay for the estimation of suspended sediment concentration in tropical waters. International Journal of Remote Sensing, 24(16), 3235-3245. https://doi.org/10.1080/01431160110114934

Glymph, L. M. (1973, November 15). Summary: Sedimentation of Reservoirs. Man-Made Lakes: Their Problems and Environmental Effects. https://doi.org/doi:10.1029/GM017p0342

Jensen, J. R. (2007). Application of high spatial resolution satellite imagery for riparian and forest ecosystem classification. Remote Sensing of the Environment, 110(1), 29-44. https://doi.org/10.1016/j.rse.2007.02.014

Karabulut, M., \& Ceylan, N. (2005). The spectral reflectance responses of water with diferente levels of suspended sedments in the presence of algae. Turkish Journal of Engineering and Environmental Sciences, 29, 351-360.

Kim, H.-C., Son, S., Kim, Y. H., Khim, J. S., Nam, J., Chang, W. K., .. Ryu, J. (2017). Remote sensing and water quality indicators in the Korean West coast: Spatio-temporal structures of MODIS-derived chlorophyll-a and total suspended solids. Marine Pollution Bulletin, 121(1), 425-434. https://doi.org/ 10.1016/j.marpolbul.2017.05.026

Krol, M. S., de Vries, M. J., van Oel, P. R., \& de Araújo, J. C. (2011). Sustainability of Small Reservoirs and Large Scale Water Availability Under Current Conditions and Climate Change. Water Resources Management, 25(12), 3017-3026. https://doi.org/10.1007/s11269-011-9787-0

Li, X.-G., \& Wei, X. (2008). An improved genetic algorithm-simulated annealing hybrid algorithm for the optimization of multiple reservoirs. Water Resources Management, 22(8), 1031-1049. https://doi.org/ $10.1007 / \mathrm{s} 11269-007-9209-5$

Lima Neto, I. E., Wiegand, M. C., \& de Araújo, J. C. (2011). Sediment redistribution due to a dense reservoir network in a large semi-arid Brazilian basin. Hydrological Sciences Journal, 56(2), 319-333. https://doi.org/ $10.1080 / 02626667.2011 .553616$

Lira, D., Toledo, C., \& Mamede, G. (2014). Silting in the dense reservoir network of the Pereira de Miranda catchment. Engenharia Agrícola, 34(4), 671-682. https://doi.org/10.1590/S0100-69162014000400007

Lodhi, M. A., Rundquist, D. C., Han, L., \& Kuzila, M. S. (2007). The potential for remote sensing of loess soils suspended in surface waters. JAWRA Journal of the American Water Resources Association, 33(1), 111-117. https://doi.org/10.1111/j.1752-1688.1997.tb04087.x

Lopes, F. B., Barbosa, C. C. F., Novo, E. M. L. de M., Andrade, E. M. de, \& Chaves, L. C. G. (2014). Modelagem da qualidade das águas a partir de sensoriamento remoto hiperespectral. Revista Brasileira de Engenharia Agrícola e Ambiental, 18(Suppl.), 13-19. https://doi.org/10.1590/1807-1929/agriambi.v18n supps13-s19

Malveira, V. T., de Araújo, J. C., \& Güntner, A. (2012). Hydrological impact of a high-density reservoir network in semiarid northeastern Brazil. Journal of Hydrologic Engineering, 17(1), 109-117. https://doi.org/10.1061/ (ASCE)HE.1943-5584.0000404

Mamede, G. L. (2008). Reservoir sedimentation in dryland catchments: Modelling and management. University of Potsdam.

Mantovani, J. E., \& Novo, E. M. L. de M. (1996). Comportamento Espectral da Matéria Orgânica Dissolvida (pp. 917-923). Simpósio Brasileiro de Sensoriamento Remoto, Salvador.

Minear, J. T., \& Kondolf, G. M. (2009). Estimating reservoir sedimentation rates at large spatial and temporal scales: A case study of California. Water Resources Research, 45(12). https://doi.org/10.1029/2007WR 006703 
Minella, J. P. G., Merten, G. H., \& Clarke, R. T. (2009). Método "fingerprinting” para identificação de fontes de sedimentos em bacia hidrográfica rural. Revista Brasileira de Engenharia Agrícola e Ambiental, 13(5), 633-638. https://doi.org/10.1590/S1415-43662009000500017

Mobley, C. D. (1994). Light and water: Radiative transfer in natural waters (Academic P).

Nash, J. E., \& Sutcliffe, J. V. (1970). River flow forecasting through conceptual models part I - A discussion of principles. Journal of Hydrology, 10(3), 282-290. https://doi.org/10.1016/0022-1694(70)90255-6

Navarro-Hevia, J., Lima-Farias, T. R., de Araújo, J. C., Osorio-Peláez, C., \& Pando, V. (2016). Soil Erosion in Steep Road Cut Slopes in Palencia (Spain). Land Degradation \& Development, 27(2), 190-199. https://doi.org/10.1002/ldr.2459

Novo, E. M. L. de M. (2005). Sensoriamento remoto aplicado à ecologia aquática. In F. Roland, D. César, \& M. Marinho (Eds.), Lições de limnologia (RiMa, pp. 417-432). São Carlos.

Okumura, Y. (1995, November 15). Sedimentation of suspended matter in the mouth of the Ane River. Physical Processes in a Large Lake: Lake Biwa, Japan. https://doi.org/10.1029/CE048p0119

Ostrovsky, I., \& Tęgowski, J. (2010). Hydroacoustic analysis of spatial and temporal variability of bottom sediment characteristics in Lake Kinneret in relation to water level fluctuation. Geo-Marine Letters, 30(3), 261-269. https://doi.org/10.1007/s00367-009-0180-4

Poleto, C., Merten, G. H., \& Minella, J. P. (2009). The identification of sediment sources in a small urban watershed in southern Brazil: An application of sediment fingerprinting. Environmental Technology, 30(11), 1145-1153. https://doi.org/10.1080/09593330903112154

Rãdoane, M., \& Rãdoane, N. (2005). Dams, sediment sources and reservoir silting in Romania. Geomorphology, 71(1), 112-125. https://doi.org/10.1016/j.geomorph.2004.04.010

Renó, V. F., Moraes, L. E. S., Saito, E. A., Nascimento, R. F. F., Lobo, L. F., Samizava, T. M., \& Novo, E. M. L. de M. (2009). Caracterização Espectral das Águas da Planície do Rio Paraná a partir de Imagens Landsat TM (pp. 4821-4828). Simpósio Brasileiro de Sensoriamento Remoto, Natal.

Rijsdijk, A., Sampurno Bruijnzeel, L. A., \& Sutoto, C. K. (2007). Runoff and sediment yield from rural roads, trails and settlements in the upper Konto catchment, East Java, Indonesia. Geomorphology, 87(1-2), 28-37. https://doi.org/10.1016/j.geomorph.2006.06.040

Rudorff, C. M., Novo, E. M. L. M., Galvao, L. S., \& Pereira Filho, W. (2007). Análise derivativa de dados hiperespectrais medidos em nível de campo e orbital para caracterizar a composição de águas opticamente complexas na Amazônia. Acta Amaz., 37(2), 269-280. https://doi.org/10.1590/S0044-59672007000200014

Teegavarapu, R. S. V, \& Simonovic, S. P. (2002). Optimal operation of reservoir systems using simulated annealing. Water Resources Management, 16(5), 401-428. https://doi.org/10.1023/A:1021993222371

Tiecher, T., Minella, J. P. G., Evrard, O., Caner, L., Merten, G. H., Capoane, V., ... dos Santos, D. R. (2018). Fingerprinting sediment sources in a large agricultural catchment under no-tillage in Southern Brazil (Conceição River). Land Degradation \& Development, 29(4), 939-951. https://doi.org/10.1002/ldr.2917

Valerio, A. de M., Kampel, M., Vantrepotte, V., Ward, N. D., Sawakuchi, H. O., Less, D. F. D. S., ... Richey, J. (2018). Using CDOM optical properties for estimating DOC concentrations and pCO2 in the Lower Amazon River. Optics Express, 26(14), A657-A677. https://doi.org/10.1364/OE.26.00A657

Wang, J.-J., \& Lu, X. X. (2010). Estimation of suspended sediment concentrations using Terra MODIS: An example from the Lower Yangtze River, China. Science of The Total Environment, 408(5), 1131-1138. https://doi.org/10.1016/j.scitotenv.2009.11.057

Yang, X., Sokoletsky, L., Wei, X., \& Shen, F. (2017). Suspended sediment concentration mapping based on the MODIS satellite imagery in the East China inland, estuarine, and coastal waters. Chinese Journal of Oceanology and Limnology, 35(1), 39-60. https://doi.org/10.1007/s00343-016-5060-y

Zhang, S., Foerster, S., Medeiros, P., de Araújo, J. C., Motagh, M., \& Waske, B. (2016). Bathymetric survey of water reservoirs in north-eastern Brazil based on TanDEM-X satellite data. Science of The Total Environment, 571, 575-593. https://doi.org/10.1016/j.scitotenv.2016.07.024

Ziegler, A. D., Negishi, J. N., Sidle, R. C., Gomi, T., Noguchi, S., \& Nik, A. R. (2007). Persistence of road runoff generation in a logged catchment in Peninsular Malaysia. Earth Surface Processes and Landforms, 32(13), 1947-1970. https://doi.org/10.1002/esp.1508 


\section{Copyrights}

Copyright for this article is retained by the author(s), with first publication rights granted to the journal.

This is an open-access article distributed under the terms and conditions of the Creative Commons Attribution license (http://creativecommons.org/licenses/by/4.0/). 